\title{
Multiple resistance to acetolactate synthase (ALS)- and acetyl-coenzyme A carboxylase (ACCase)-inhibiting herbicides in black-grass (Alopecurus myosuroides Huds.) populations from Poland
}

\author{
Kazimierz Adamczewski, Roman Kierzek, Kinga Matysiak* \\ Department of Weed Science, Institute of Plant Protection - National Research Institute, \\ Władysława Węgorka 20, 60-318 Poznań, Poland
}

Received: July 20, 2016

Accepted: November 14, 2016

\begin{abstract}
Alopecurus myosuroides seeds were sampled from 32 winter wheat fields from 2010 to 2014. Resistance to herbicides was detected in 17 A. myosuroides populations. In addition to single resistance to herbicides, cross-resistance and multiple resistance to acetolactate synthase (ALS)- and acetyl-coenzyme A carboxylase (ACCase)-inhibiting herbicides were found. Application of sulfometuron and imazapyr was unable to control some of the resistant biotypes in this study. This result implies that resistance in these populations is due to a target site mechanism. The A. myosuroides biotypes resistant to ACCase-inhibiting herbicides varied in their responses to derivatives of aryloxy-phenoxy-propionic acid (FOPs), cyclohexanediones (DIMs) and phenylpyrazolines (DENs). Resistant biotypes of $A$. myosuroides that could not be controlled with fenoxaprop-P-ethyl (FOP) and pinoxaden (DEN) were controlled with clethodim (DIM).
\end{abstract}

Key words: clethodim, fenoxaprop-P-ethyl, imazapyr, jodosulfuron + mezosulfuron, mechanism of resistances, pinoxaden, sulfometuron

\section{Introduction}

Alopecurus myosuroides Huds. is a major weed in many Western European countries. This weed prefers good, compact, clay soils and rendzinas that are rich in nutrients and moderately moist. In Poland, where infestations of this weed have been increasing for many years, A. myosuroides poses a challenge to the cultivation of winter and spring cereal crops and winter oilseed rape, sugar beet and legumes. Mass occurrence of A. myosuroides has been observed in Żuławy, the northeastern Warmian-Masurian region, Chełmno County (Vistula River Valley), Lubusz Land (Oder River Valley) and Pyrzyce County, as well as in Lower Silesian and Opole Counties. Alopecurus myosuroides is estimated to have infested $250,000-350,000$ ha in Poland, thus requiring that its population be controlled.

Both acetolactate synthase (ALS)- and acetyl-coenzyme A carboxylase (ACCase)-inhibiting herbicides are commonly used for weed control of $A$. myosuroides. In Europe, the first herbicide-resistant biotypes of $A$. myosuroides were recorded in 1982 in Great Britain (Moss and Cussans 1985). Alopecurus myosuroides is now deemed to be the major resistant weed in 10 European countries. The greatest resistance problem is found in England, with an increasing trend observed in France and Germany (Delye et al. 2003; Moss et al. 2003, 2007). The occurrence of A. myosuroides resistant to sulfonylurea herbicides has also been noted in Poland (Adamczewski et al. 2010). In countries where herbicide resistance is highly problem- atic, numerous experiments have been conducted with the aim of developing a program for the control of resistant A. myosuroides biotypes (Cavan et al. 2000; Chauvel et al. 2001; Moss et al. 2007). Mutations at five ACCase (Ile-1781, Trp-2027, Ile-2041, Asp-2078 and Gly-2096) and two ALS (Pro-197 and Trp-574) codons of A. myosuroides are currently known to impact the efficacies of ACCaseand ALS-inhibiting herbicides (Adamczewski et al. 2010; Krysiak et al. 2011; Petersen and Rosenbauer 2014). Because several mechanisms underlying the development and inheritance of resistance genes exist in A. myosuroides, the species has become a model plant to investigate these phenomena (Letouzé and Gasquez 2001, 2003; Milner et al. 2001; Delye et al. 2007). According to a study conducted by Krzakowa and Adamczewski (2011), no geographic correlation exists among populations of A. myosuroides from different regions of Poland. In addition to exhibiting high genetic polymorphism, these populations are more variable in terms of phosphoglucoisomerase than in regard to diaphorase (DIA).

Because of the prohibition of several active substances in accordance with European Union (EU) legal regulations and the lack of new substances to replace them, chemical control of $A$. myosuroides is becoming increasingly difficult. As a result, planters have limited practical options to chemically control A. myosuroides and are forced to use herbicides from two main chemical groups, i.e., ALS- and ACCase-inhibiting herbicides. The herbi- 
cides most frequently used to control $A$. myosuroides in practice are fenoxaprop-P-ethyl (Puma Universal 69 EW), pinoxaden (Axial $50 \mathrm{EC}$ ) and jodosulfuron + mezosulfuron (Atlantis 12 OD). Common and wide use of these substances for many years has led to their decreased or total loss of effectiveness against $A$. myosuroides.

The present study aimed to: 1) determine whether multiple resistance to ALS- and ACCase-inhibiting herbicides exists in Polish populations of A. myosuroides; 2) specify the mechanism governing resistance to ALS-inhibiting herbicides; and 3) compare the effectiveness of the following three groups of ACCase-inhibiting herbicides for the control of resistant $A$. myosuroides biotypes: derivatives of aryloxy-phenoxy-propionic acid (FOPs), cyclohexanediones (DIMs) and phenylpyrazolines (DENs).

\section{Materials and Methods}

\section{Sample collection}

At the beginning of each July from 2010 to 2014, 32 samples of $A$. myosuroides seeds were collected from winter wheat fields. These fields were located in several regions of Poland where A. myosuroides has been poorly controlled despite herbicide applications. Mature A. myosuroides plant samples were also collected from many sites to represent entire fields or areas in which herbicides have functioned inefficiently. One ear was collected per plant, with approximately 50-60 plants collected per field.

\section{Greenhouse experiments}

After drying, seeds were cleaned in the laboratory and stored for one week in a refrigerator at approximately $-5^{\circ} \mathrm{C}$ to break seed dormancy. The prepared seeds were then subjected to greenhouse experiments to determine their resistance towards selected herbicides. Three kinds of greenhouse experiments were performed. During the first stage of the study, five herbicides at recommended and double doses were applied: fenoxaprop-P-ethyl (Puma Universal $69 \mathrm{EW}$ ), jodosulfuron + mezosulfuron (Atlantis 12 OD), pinoxaden (Axial 50 EC), aminopyralid + pyroxsulam + florasulam (Lancet Plus $125 \mathrm{WG)}$ and isoproturon (Tolurex $500 \mathrm{SC}$ ). This experiment, which was conducted under greenhouse conditions on the $32 \mathrm{sam}$ ples, allowed us to select biotypes not controlled by the five applied herbicides. Five populations were selected for the second experiment: two populations from the Lubusk region in the Oder Valley (Bieganów I - R2 and Bieganów IIa - R3), one population located north of Torun in the Kuyavian-Pomeranian region (Borówno - R6), and two populations from northeastern Poland (Sułowo - R7 and Łabędnik - R8). Because a Pro197-to-His mutation had been previously discovered in molecular studies of the R2 biotype (Adamczewski et al. 2010; Krysiak et al. 2011), this biotype was used as a resistant standard reference biotype in our study. In the above mentioned studies the sensitive biotype was also involved. To determine regression curves and calculate resistance coefficients, selected biotypes were treated with herbicides at eight doses: jo- dosulfuron + mezosulfuron (Atlantis 12 OD) at doses of $2.4(2+0.4)$ to $192.0(160+32) \mathrm{g} \cdot \mathrm{ha}^{-1}$, sulfometuron (Oust $75 \mathrm{WG}$ ) at $18.25-1,500 \mathrm{~g} \cdot \mathrm{ha}^{-1}$, pinoxaden (Axial $\left.50 \mathrm{EC}\right)$ at 6.25-500 g $\cdot$ ha $^{-1}$, fenoxaprop-P-ethyl (Puma Universal 69 EW) at 17.25-690 g $\cdot \mathrm{ha}^{-1}$, imazapyr (Arsenal 120 SL) at 7.5$600 \mathrm{~g} \cdot \mathrm{ha}^{-1}$ and clethodim (Select Super $120 \mathrm{EC}$ ) at 9-720 g . $\cdot \mathrm{ha}^{-1}$. The third experiment analyzed the effectiveness of three groups of ACCase-inhibiting herbicides, i.e., FOPs, DIMs and DENs, in the control of the selected resistant A. myosuroides biotypes. The herbicides were applied at three doses: at 50\%, $100 \%$ and twice the recommended dose. Doses per ha were as follows: $41.4,82.8$ and $165.6 \mathrm{~g}$ of fenoxaprop-P-ethyl (Puma Universal 69 EW); 22.5, 45 and $90 \mathrm{~g}$ of pinoxaden (Axial $50 \mathrm{EC}$ ); and 60, 120 and $240 \mathrm{~g}$ of clethodim (Select Super 120 EC). The standard sample used in all experiments was a susceptible biotype (S) collected in Gołuski near Poznań. All greenhouse experiments were repeated four times in 0.5-1 plastic pots (9 $\mathrm{cm}$ diameter). Horticultural soil mixed with sand at a $3: 1$ ratio was used as the substrate for the experiments. The soil contained $1.89 \%$ organic matter and had a $\mathrm{pH}$ of 6.2. Approximately 20-25 seeds were planted in each pot. After emergence, plants were thinned to 10 plants per pot. Greenhouse conditions included a temperature of $20-25^{\circ} \mathrm{C}$ and a $16: 8 \mathrm{~h}(\mathrm{~L}: \mathrm{D})$ photoperiod and with a light intensity of $\approx 150 \mu \mathrm{mol} \cdot \mathrm{m}^{-2} \cdot \mathrm{s}^{-1}$. Herbicides were applied to three to four leaves of each plant with a greenhouse sprayer equipped with a TeeJet TT 11002 spray nozzle at a pressure of $0.3 \mathrm{MPa}$. For application $250 \mathrm{l} \cdot \mathrm{ha}^{-1}$ of water was used. The effects of each herbicide were assessed 25 days after application by recording the green biomass of aboveground parts of 10 plants.

\section{Data analysis}

A statistical analysis to calculate the dose-response curves was performed on the percentage loss of green biomass of each plant compared with the control (untreated plants). A regression curve was specified for each biotype, with a 0.05 confidence limit. The herbicide application rate causing $50 \%$ reduction in growth was estimated by nonlinear regression analysis using SigmaPlot software. The data were fitted to a three-parameter logistic curve model (Jalaludin et al. 2014):

$$
y=\frac{a}{1+\left(\frac{x}{E D_{50}}\right)^{b}}
$$

where: $a$ - the upper limit; $E D_{50}$ - the estimated dose causing $50 \%$ response (growth reduction $G R_{50}$ ); $b$ - the slope around $E D_{50}$

Growth reduction $G R_{50}$ values of susceptible and resistant biotypes were used to calculate the resistance : susceptible $(\mathrm{R}: \mathrm{S})$ ratio of the resistant population. Several pilot trials were performed prior to the final herbicide dose-response experiments, which contained at least four replicate pots per herbicide application rate. Each dose-response experiment was repeated at least twice with similar results; therefore, only results from a single experiment are presented for each dose response. 
Data representing the percentage loss of green biomass in the third experiment, which compared the effects of three herbicides applied in three doses, were subjected to Freeman-Tukey transformation and analysis of variance at a confidence limit of $\alpha=0.05$ using Statistica v.10 software (StatSoft, Poland).

\section{Results}

The first set of greenhouse experiments conducted on 32 A. myosuroides samples showed herbicide resistance in 17 populations (Table 1) in different regions throughout Poland (Fig. 1). Resistance to two groups of herbicides, namely ALS- and ACCase-inhibiting herbicides, was observed. According to these results, resistant biotypes of A. myosuroides can be found in the Żuławy area and in the southwestern and northeastern parts of the country. Resistance was also observed in Chełmno County in the Vistula Valley and in Kołobrzeg County (Fig. 1). Resistant biotypes of $A$. myosuroides occur in regions where this type of weed is highly problematic, and the herbicides from the above two chemical groups are commonly used to control it. To specify effective herbicide doses and calculate resistance indices, five biotypes resistant to jodosulfuron + mezosulfuron were selected for further studies (Table 2). The effects of three active substances (ALS-inhibiting herbicides) on green biomass production of the five resistant $A$. myosuroides biotypes and the susceptible standard are shown in Figures 2-4. Figures 5-7 show green biomass reduction in the same five resistant biotypes and the susceptible standard after application of three ACCase-inhibiting herbicides. Dosages from $31.2 \mathrm{~g}$ (for the $\mathrm{R} 6$ biotype) to $53.1 \mathrm{~g}$ (for the R5 biotype) were re- quired to obtain a $50 \%$ reduction in green biomass in the biotypes (R2, R3, R6, R7 and R8) resistant to jodosulfuron + mezosulfuron (Fig. 2, Table 2). To achieve the same results with the susceptible biotype (S), only $2.0 \mathrm{~g}$ of jodosulfuron + mezosulfuron had to be applied. Control of R2, R3, R7 and R8 biotypes by sulfometuron (Fig. 3, Table 2) was also weak, with resistance indices ranging from 24.1 for the R3 biotype to 34.4 for the R7 biotype (Table 2). These results may suggest that the resistance of these biotypes is due to target-site resistance, probably at Pro-197. The R6 biotype was well controlled by sulfometuron at a level similar to that of the standard susceptible biotype (the $S$ biotype). A non-target-site resistance mechanism to ALS-inhibiting herbicides is thus very likely operating in this biotype. As shown in Figure 4, biotypes R2, R3 and R8 were resistant to imazapyr. Resistance coefficients for these biotypes ranged from 20.6 ( $\mathrm{R} 2$ biotype) to 30.5 ( $\mathrm{R} 8$ biotype). Two biotypes resistant to jodosulfuron + mezosulfuron, namely R6 and R7, turned out to be susceptible to imazapyr, with resistance coefficients of 1.5-1.6. The results of this comparison demonstrate that $\mathrm{R} 2, \mathrm{R} 3$ and R8 biotypes (Figs. 3 and 4) can exhibit cross-resistance.

The effects of the three ACCase-inhibiting herbicides on the five A. myosuroides biotypes resistant to jodosulfuron + mezosulfuron are shown in Figures 5-7. Fenoxaprop-P-ethyl (FOP), pinoxaden (DEN) and clethodim (DIM) were applied. Four A. myosuroides biotypes - R3, R6, R7 and R8 (Figs. 5 and 6) - were resistant to fenoxaprop-P-ethyl and pinoxaden. The fenoxaprop-P-ethyl resistance coefficients for these biotypes ranged from 13.4 for the R2 biotype to 14.7 for the R8 biotype. The pinoxaden resistance coefficients varied from 11.9 for the R8 biotype to 30.5 for the R7 biotype. The R2 biotype

Table 1. Occurrence of resistant Alopecurus myosuroides biotypes according to herbicide mode of action

\begin{tabular}{|c|c|c|c|}
\hline \multirow{2}{*}{$\begin{array}{l}\text { Number on } \\
\text { map }\end{array}$} & \multirow{2}{*}{ Sampling place } & \multicolumn{2}{|c|}{ Resistance to herbicide inhibitors } \\
\hline & & ALS & ACCase \\
\hline 1 & Pyrzyce & a & - \\
\hline 2 & Bieganów I & $a, b, c$ & - \\
\hline 3 & Bieganów IIa & $a, b, c$ & $d, e, f$ \\
\hline 4 & Bieganów IIb & a & d, e \\
\hline 5 & Kopanica n/Darłowo & a & $\mathrm{d}$ \\
\hline 6 & Borówno/Unisław & a & d, e \\
\hline 7 & Sułowo & $\mathrm{a}, \mathrm{b}$ & d, e \\
\hline 8 & Łabędnik & $a, b, c$ & $d, e, f$ \\
\hline 9 & Maszewy & - & d, e \\
\hline 10 & Nowy Dwór Gdański & - & d, e \\
\hline 11 & Kmiecin & a & - \\
\hline 12 & Gołębiewko & a & - \\
\hline 13 & Gnojno & - & $\mathrm{d}$ \\
\hline 14 & Wojsław & a & - \\
\hline 15 & Lubcz & - & d \\
\hline 16 & Rosochota & a & - \\
\hline 17 & Rogożnik & - & $\mathrm{d}$ \\
\hline
\end{tabular}

a - jodosulfuron + mezosulfuron (Atlantis 12 OD); b - sulfometuron (Oust 75 WG); c - imazapyr (Arsenal 120 SL); d - fenoxaprop-P-ethyl (Puma Universal 69 EW); e - pinoxaden (Axial 50 EC); f - clethodim (Select Super 120 EC); ALS - acetolactate synthase; ACCase - acetyl-coenzyme A carboxylase 


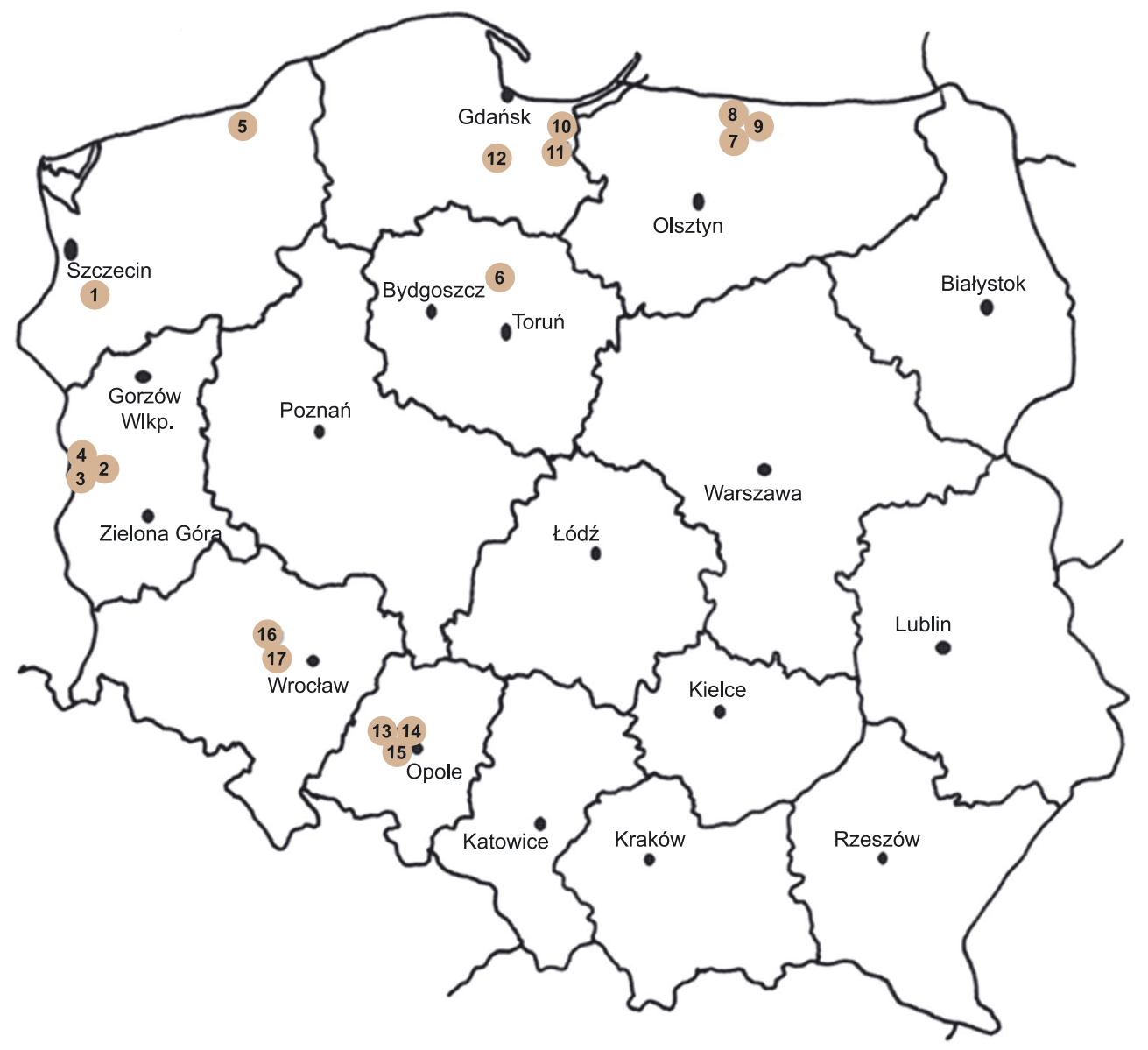

Fig. 1. Geographical location of black-grass (Alopecurus myosuroides) resistance on herbicides in Poland

Table 2. Resistance parameters based on fresh biomass of Alopecurus myosuroides biotypes

\begin{tabular}{|c|c|c|c|c|c|c|}
\hline \multirow{3}{*}{$\begin{array}{c}\text { Number of } \\
\text { biotypes - place }\end{array}$} & \multicolumn{6}{|c|}{ ALS inhibitors } \\
\hline & \multicolumn{2}{|c|}{ jodosulfuron + mezosulfuron } & \multicolumn{2}{|c|}{ sulfometuron } & \multicolumn{2}{|c|}{ imazapyr } \\
\hline & $E D_{50}$ & $\mathrm{R}: \mathrm{S}^{*}$ & $E D_{50}$ & $\mathrm{R}: \mathrm{S}^{*}$ & $E D_{50}$ & $\mathrm{R}: \mathrm{S}^{*}$ \\
\hline S Standard & $\begin{array}{c}2.0 \\
(1.7-2.3)\end{array}$ & 1 & $\begin{array}{c}15.2 \\
(13.1-17.3)\end{array}$ & 1 & $\begin{array}{c}5.2 \\
(4.4-6.0)\end{array}$ & 1 \\
\hline R2 Bieganów I & $\begin{array}{c}40.3 \\
(38.2-42.6)\end{array}$ & 17.6 & $\begin{array}{c}430.2 \\
(410.0-451.0)\end{array}$ & 28.3 & $\begin{array}{c}107.2 \\
(101.1-113.5)\end{array}$ & 20.6 \\
\hline R3 Bieganów IIa & $\begin{array}{c}49.1 \\
(46.7-51.6)\end{array}$ & 24.6 & $\begin{array}{c}366.0 \\
(347.5-385.1)\end{array}$ & 24.1 & $\begin{array}{c}146.4 \\
(138.4-154.6)\end{array}$ & 28.2 \\
\hline R6 Borówno & $\begin{array}{c}31.2 \\
(29.6-33.0)\end{array}$ & 15.6 & $\begin{array}{c}21.8 \\
(19.5-24.0)\end{array}$ & 1.4 & $\begin{array}{c}8.2 \\
(7.7-9.1)\end{array}$ & 1.6 \\
\hline R7 Sułowo & $\begin{array}{c}40.9 \\
(38.9-43.1)\end{array}$ & 20.5 & $\begin{array}{c}523.2 \\
(501.2-545.5)\end{array}$ & 34.4 & $\begin{array}{c}7.7 \\
(6.9-8.6)\end{array}$ & 1.5 \\
\hline \multirow[t]{4}{*}{ R8 Łabędnik } & $\begin{array}{c}53.1 \\
(50.5-55.8)\end{array}$ & 26.6 & $\begin{array}{c}472.2 \\
(441.2-505.7)\end{array}$ & 31.1 & $\begin{array}{c}158.6 \\
(150.3-167.1)\end{array}$ & 30.5 \\
\hline & \multicolumn{6}{|c|}{ ACCase inhibitors } \\
\hline & \multicolumn{2}{|c|}{ fenoxaprop-P-ethyl } & \multicolumn{2}{|c|}{ pinoxaden } & \multicolumn{2}{|c|}{ clethodim } \\
\hline & $E D_{50}$ & $\mathrm{R}: \mathrm{S}^{*}$ & $E D_{50}$ & $\mathrm{R}: \mathrm{S}^{*}$ & $E D_{50}$ & $\mathrm{R}: \mathrm{S}^{*}$ \\
\hline S Standard & $\begin{array}{c}15.4 \\
(13.7-17.1)\end{array}$ & 1 & $\begin{array}{c}5.6 \\
(4.9-6.3)\end{array}$ & 1 & $\begin{array}{c}7.4 \\
(6.5-8.3)\end{array}$ & 1 \\
\hline R2 Bieganów I & $\begin{array}{c}40.5 \\
(37.5-43.6)\end{array}$ & 2.6 & $\begin{array}{c}12.3 \\
(11.1-13.5)\end{array}$ & 2.2 & $\begin{array}{c}9.5 \\
(8.4-10.4)\end{array}$ & 1.3 \\
\hline R3 Bieganów IIa & $\begin{array}{c}180.7 \\
(173.4-188.3)\end{array}$ & 11.7 & $\begin{array}{c}55.8 \\
(52.3-59.4)\end{array}$ & 10.0 & $\begin{array}{c}30.1 \\
(27.5-32.9)\end{array}$ & 4.1 \\
\hline R6 Borówno & $\begin{array}{c}208.5 \\
(200.2-217.2)\end{array}$ & 13.5 & $\begin{array}{c}111.2 \\
(105.7-117.0)\end{array}$ & 19.9 & $\begin{array}{c}10.0 \\
(9.0-11.0)\end{array}$ & 1.4 \\
\hline R7 Sułowo & $\begin{array}{c}206.9 \\
(198.6-215.5)\end{array}$ & 13.4 & $\begin{array}{c}170.9 \\
(163.9-178.0)\end{array}$ & 30.5 & $\begin{array}{c}8.1 \\
(7.2-9.0)\end{array}$ & 1.1 \\
\hline R8 Łabędnik & $\begin{array}{c}226.5 \\
(217.6-235.8) \\
\end{array}$ & 14.7 & $\begin{array}{c}66.6 \\
(62.7-70.8) \\
\end{array}$ & 11.9 & $\begin{array}{c}19.8 \\
(17.8-21.8) \\
\end{array}$ & 2.8 \\
\hline
\end{tabular}

${ }^{*} \mathrm{R}: \mathrm{S}$ - resistance coefficient; lower and upper bound at $95 \%$ probability in parenthesis; ALS - acetylactate synthase; ACCase acetyl-coenzyme A carboxylase 


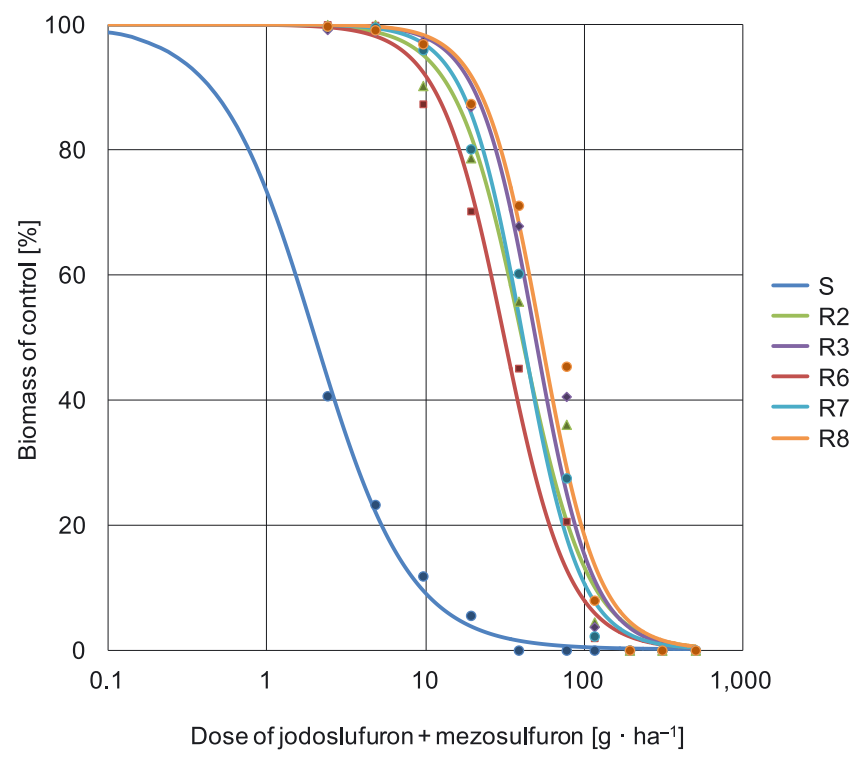

Fig. 2. Influence of jodosulfuron + mezosulfuron on fresh mass reduction of resistant (R2, R3, R6, R7, R8) and susceptible (S) biotypes of Alopecurus myosuroides

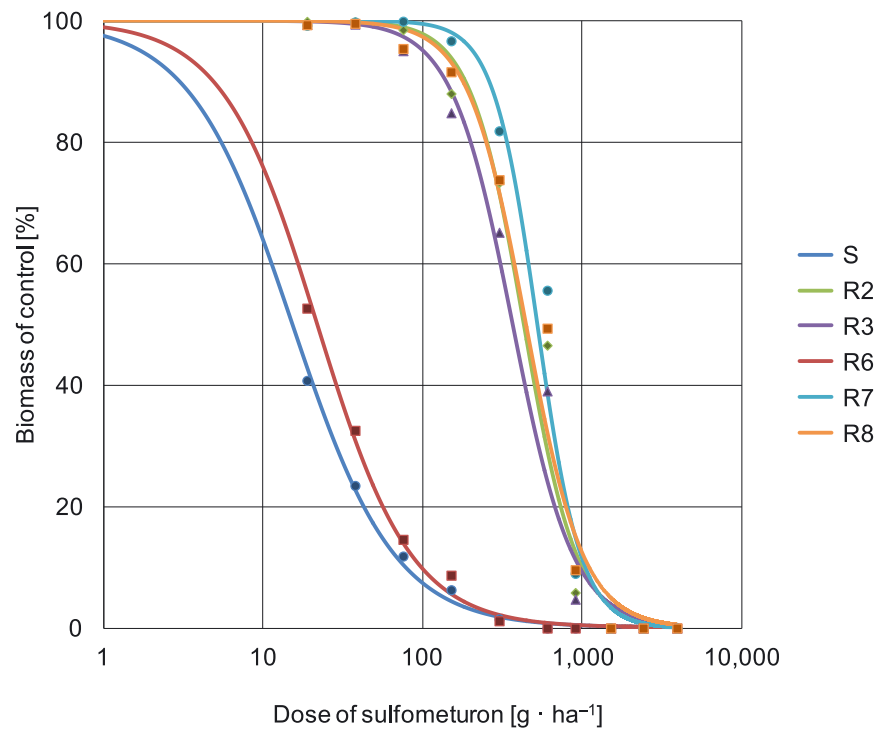

Fig. 3. Influence of sulfometuron on fresh mass reduction of resistant (R2, R3, R7, R8) and susceptible (S, R6) biotypes of Alopecurus myosuroides

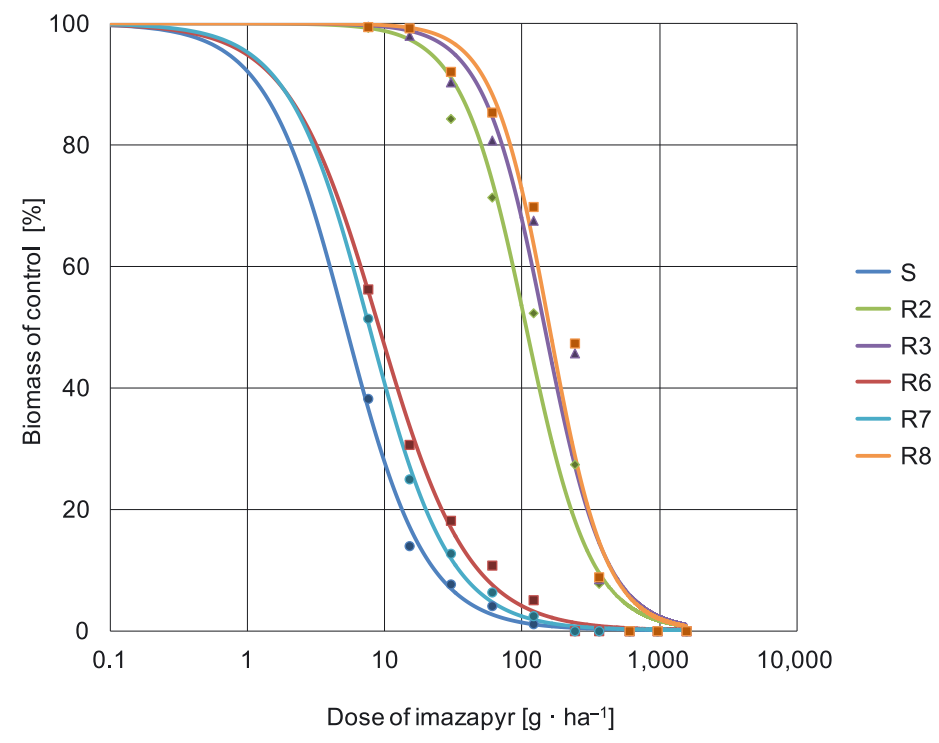

Fig. 4. Influence of imazapyr on fresh mass reduction of resistant (R2, R3, R8) and susceptible (S, R4, R6) biotypes of Alopecurus myosuroides 


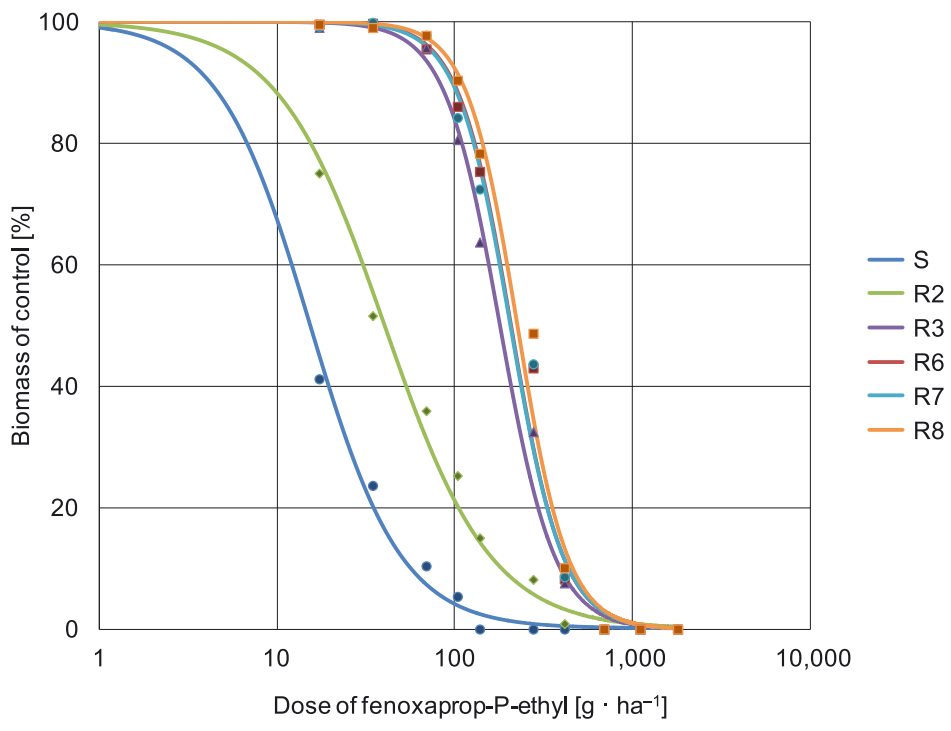

Fig. 5. Influence of fenoxaprop-P-ethyl on fresh mass reduction of resistant (R2, R3, R6, R7, R8) and susceptible (S) biotypes of Alopecurus myosuroides

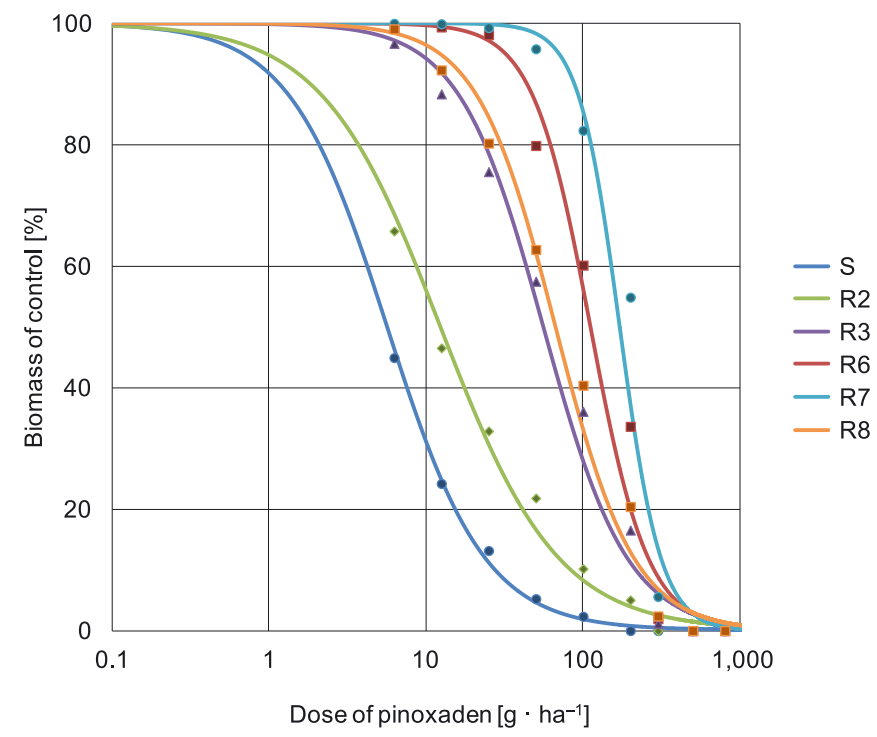

Fig. 6. Influence of pinoxaden on fresh mass reduction of resistant (R2, R3, R6, R7, R8) and susceptible (S) biotypes of Alopecurus myosuroides

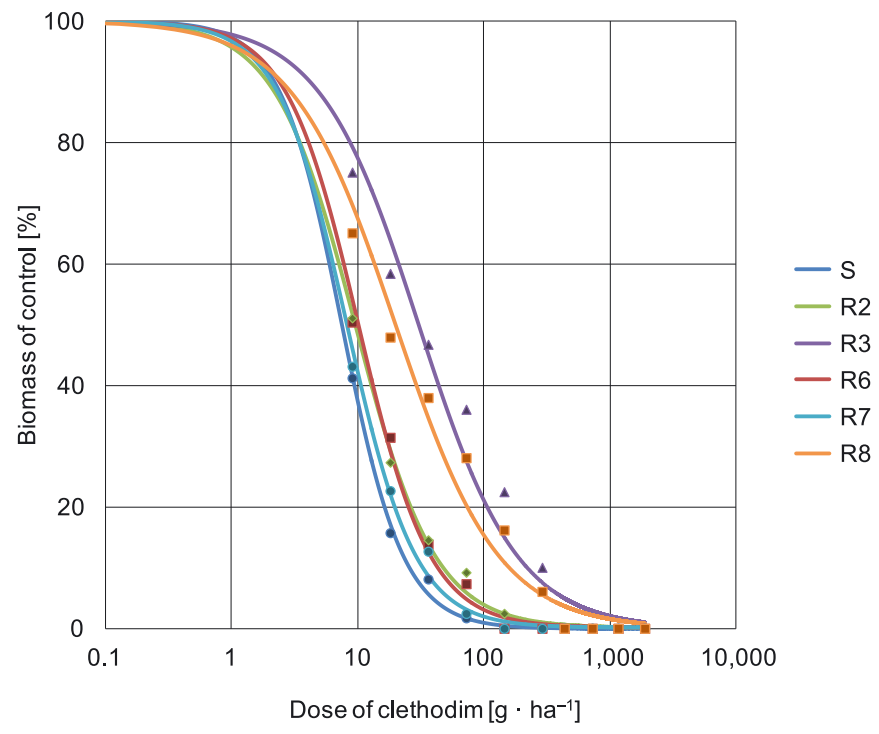

Fig. 7. Influence of clethodim on fresh mass reduction of resistant (R3, R8) and susceptible (S, R2, R6, R7) biotypes of Alopecurus myosuroides 
Table 3. The influence of three active ingredients of acetyl-coenzyme A carboxylase (ACCase) inhibitors on fresh weight loss percentage of six biotypes of Alopecurus myosuroides (mean of 10 plants)

\begin{tabular}{|c|c|c|c|c|c|c|c|}
\hline \multirow{2}{*}{ Herbicides } & \multirow{2}{*}{$\begin{array}{l}\text { Recommended } \\
\quad \text { dose }=1\end{array}$} & \multicolumn{6}{|c|}{ Biotypes } \\
\hline & & $\mathrm{S}$ & R2 & R3 & R6 & R7 & R8 \\
\hline \multirow{3}{*}{$\begin{array}{l}\text { Fenoxaprop-p- } \\
\text { ethyl }\end{array}$} & $1 / 2$ & $89.6 \mathrm{e}$ & $64.1 \mathrm{~g}$ & $4.8 \mathrm{~h}$ & $4.5 \mathrm{~g}$ & $2.2 \mathrm{de}$ & $2.3 \mathrm{~g}$ \\
\hline & 1 & $94.6 \mathrm{c}$ & $74.7 \mathrm{e}$ & $19.4 \mathrm{~g}$ & $14.0 \mathrm{f}$ & $15.8 \mathrm{c}$ & $9.6 \mathrm{f}$ \\
\hline & $2 \times 1$ & $100 \mathrm{a}$ & 87.7 c & $36.1 \mathrm{e}$ & $24.7 \mathrm{~d}$ & $27.6 \mathrm{~b}$ & $21.7 \mathrm{e}$ \\
\hline \multirow{3}{*}{ Pinoxaden } & $1 / 2$ & $86.8 \mathrm{f}$ & $67.1 \mathrm{f}$ & $24.4 \mathrm{f}$ & $1.9 \mathrm{~h}$ & $0.7 \mathrm{e}$ & $19.7 \mathrm{e}$ \\
\hline & 1 & $94.8 \mathrm{c}$ & $78.1 \mathrm{~d}$ & $42.5 \mathrm{~d}$ & $20.1 \mathrm{e}$ & $4.2 \mathrm{~d}$ & $37.4 \mathrm{~d}$ \\
\hline & $2 \times 1$ & $97.7 \mathrm{~b}$ & $89.8 \mathrm{~b}$ & $63.9 \mathrm{~b}$ & $39.8 \mathrm{c}$ & $17.6 \mathrm{c}$ & $59.6 \mathrm{c}$ \\
\hline \multirow{3}{*}{ Clethodim } & $1 / 2$ & $91.1 \mathrm{~d}$ & $85.4 \mathrm{c}$ & $53.2 \mathrm{c}$ & $86.1 \mathrm{~b}$ & $87.3 \mathrm{a}$ & $62.0 \mathrm{bc}$ \\
\hline & 1 & $98.3 \mathrm{ab}$ & $90.8 \mathrm{~b}$ & $63.4 \mathrm{~b}$ & $92.7 \mathrm{ab}$ & $97.6 \mathrm{a}$ & $71.9 \mathrm{ab}$ \\
\hline & $2 \times 1$ & $100 \mathrm{a}$ & $97.5 \mathrm{a}$ & $77.5 \mathrm{a}$ & $100 \mathrm{a}$ & $100 \mathrm{a}$ & $83.9 \mathrm{a}$ \\
\hline
\end{tabular}

$\mathrm{S}$ - susceptible, $\mathrm{R}$ - resistant; $\mathrm{a}-\mathrm{h}$ - statistical differences between treatments, the same letter means no difference

was moderately resistant to these herbicides, with resistance coefficients between 2.2 and 2.6 for pinoxaden and fenoxaprop-P-ethyl. The efficacy of clethodim on these biotypes was quite different (Fig. 7). Only two biotypes, R3 and R8, were moderately resistant to clethodim, with resistance coefficients of 4.1 and 2.8 , respectively. The other biotypes resistant to jodosulfuron + mezosulfuron were susceptible to clethodim.

Table 3 shows the percentage reduction of green biomass in the five biotypes under study after the application of three different doses of fenoxaprop-P-ethyl, pinoxaden and clethodim. The greatest reduction in green biomass after the application of the three herbicides was observed in the susceptible biotype. The reduction of fresh biomass in the resistant biotypes was more variable. The resistant biotypes were controlled most effectively by clethodim and least effectively by fenoxaprop-P-ethyl. The largest percentage reduction in fresh biomass was observed after application of herbicide to the R2 biotype. This was especially true in the case of fenoxaprop-P-ethyl and pinoxaden. The other resistant biotypes (R3 and R6) reacted poorly to these herbicides, especially when applied at $50 \%$ or at recommended doses. The average reduction in green biomass of the $10 \mathrm{~A}$. myosuroides plants following application of fenoxaprop-P-ethyl at three different doses varied from $11.2 \%$ for the R8 biotype to $75.5 \%$ for the R2 biotype. Application of pinoxaden to the 10 plants caused green biomass reductions from $7.5 \%$ for the R7 biotype to $78 \%$ for the R2 biotype. The resistant biotypes were highly susceptible to clethodim. Only the R3 and R8 biotypes were controlled less effectively.

\section{Discussion}

In Western Europe, herbicide-resistant biotypes of A. myosuroides pose a great problem (Cavan et al. 2000; Chauvel et al. 2001; Price et al. 2004; Rosenhauer et al. 2013; Petersen and Rosenhauer 2014). Previously conducted studies have shown that $A$. myosuroides herbicide-resistant biotypes can also be found in Poland (Adamczewski et al. 2010). Because of the threat to cultivated crops posed by A. myosuroides, many studies have been devoted to the resistance of this weed to herbicides. Data presented by Petersen and Rosenhauer (2014) demonstrated that resistance in Western Europe is mainly towards ACCase-inhibiting herbicides, while biotypes resistant to ALS-inhibiting herbicides are far less common. Many examples of A. myosuroides resistance to ACCase-inhibiting herbicides have been reported (Cocker et al. 1999; Delye et al. 2007; Rosenhauer et al. 2013). In Poland, however, our study found no differentiation in the occurrence of $A$. myosuroides biotypes resistant to ALS- vs. ACCase-inhibiting herbicides (Table 1). The results of our greenhouse experiments show that four out of five tested biotypes resistant to jodosulfuron + mezosulfuron were also resistant to fenoxaprop-P-ethyl and pinoxaden. However, these biotypes were susceptible to clethodim. Multiple herbicide resistance to ACCase- and ALS-inhibiting herbicides was also observed by Cocker et al. (1999) and Délye et al. (2003, 2007). These results indicate that A. myosuroides has developed resistance to herbicides from two different chemical groups. This situation is highly detrimental to crops, since the capacity to chemically control A. myosuroides is becoming increasingly limited. Sulfometuron and imazapyr were applied in our experiments to indirectly infer the resistance mechanism of $A$. myosuroides to ALS-inhibiting herbicides. Studies conducted by Jander et al. (2003) showed that the application of these two active substances allows weed biotypes to be selected to facilitate determination of the resistance mechanism to ALS-inhibiting herbicides and whether it is target-site or non-target-site resistance. The sulfonylureas sulfometuron and imazapyr are nonselective herbicides; in other words, they may be used to control all species but do not work in the case of specific target-site-resistant biotypes. Sulfometuron resistance is affected by both Pro-197 and Trp-574 mutations, while imazapyr is impacted by the Trp-574 but not the Pro-197 mutation. Studies devoted to the mechanism of resistance against ALS-inhibiting herbicides have demonstrated the utility of sulfometuron and imazapyr for the control of A. myosuroides (Hull and Moss 2007), Lolium rigidum Gaud. (Yu et al. 2010), Centaurea cyanus L. (Adamczewski and Kierzek 2011), Apera spica-venti (L.) P. Beauv. (Adamczewski and Matysiak 2012) 
and Avena fatua L. (Adamczewski et al. 2013). The resistance mechanism exhibited by A. myosuroides biotypes to ALS-inhibiting herbicides is both target- and non-targetsite based. Sulfometuron was not effective when applied to four biotypes resistant to sulfonylurea herbicides (R2, R3, R7 and R8), whereas imazapyr was not effective on three. Previous studies conducted by Adamczewski et al. (2010) and Krysiak et al. (2011) on the R2 biotype detected the Pro-197-His mutation. The presence of this mutation suggests that the resistance mechanism of the other biotypes is probably also target-site resistance. The resistant biotypes were collected in northeastern Poland: R7 and R8 in Mazury and R2 and R3 in the Oder Valley and Lubusz Land. Because distances between resistantbiotype sites (R2 and R3; R7 and R8) were not large, the possibility of transmission of the resistance gene through pollen was very high. A double mutation was observed in two locations in Lubusz Land (R2 and R3) and in one area in Mazury (R8). According to studies conducted by Adamczewski and Matysiak (2009), Busi et al. (2009) and Petersen et al. (2010), the gene responsible for resistance to ALS- and ACCase-inhibiting herbicides is transmitted through pollen. The R6 biotype was controlled by both sulfometuron and imazapyr, which implies that the resistance of this biotype to sulfonylurea herbicides is of the metabolic type (non-target-site resistance). The R6 biotype was collected from alluvial soils of the Vistula River Valley in Borówno, relatively far away from the other resistant biotypes. ACCase-inhibiting herbicides are commonly used to control A. myosuroides. Herbicides relying on this mechanism belong to three chemical groups: FOPs, DENs and DIMs. In another experiment, the resistant $A$. myosuroides biotypes were treated with substances from the same chemical groups. The resistant biotypes were not susceptible to FOP and DEN, but were found to be susceptible to DIM. Delye et al. (2008) showed that the resistance of $A$. myosuroides to these herbicides depends on five mutations in the ACCase gene: Ile-1781-Leu, Trp-2027-Cys, Ile-2041-Asn, Asp-2078-Gly and Gly-2096Ala. Kaundun et al. (2013) found that the Ile-1781-Leu mutation is the most common mutation in Great Britain and is responsible for the resistance of $A$. myosuroides to ACCase-inhibiting herbicides. Similar results were obtained for L. rigidum by Saini et al. (2014). The resistance of $A$. myosuroides to clethodim results exclusively from the Asp-2078-Gly mutation (Delye et al. 2008). In the biotypes investigated in this study, their lack of strong resistance to clethodim indicates that they probably do not carry the Asp-2078-Gly mutation. Some resistance of A. myosuroides to clethodim may also be caused by Ile-1781-Leu and Gly2096-Ala mutations (Saini et al. 2014). Such low resistance was also found in R3 and R8 biotypes, thus indicating that the R3 and R8 biotypes may also carry Ile-1781-Leu and Gly-2096-Ala mutations but they are non-target-site resistant. The results obtained here indicate that the resistant A. myosuroides biotypes may be controlled with clethodim graminicides, at least in broad-leaved crops. According to the results of Moss et al. (2012), the DIM clethodim is more efficient than the FOP propaquizafop against $A$. myosuroides biotypes resistant to ACCase-inhibiting herbicides.

\section{References}

Adamczewski K., Kierzek R. 2011. Mechanizm odporności chabra blawatka (Centurea cyanus L.) na herbicydy sulfonylomocznikowe [Mechanism of resistance on acetylolactate synthase (ALS) of Centaurea cyanus L. biotypes crossresistant]. Progress in Plant Protection/Postępy w Ochronie Roślin 51 (1): 317-324. (in Polish, with English summary)

Adamczewski K., Kierzek R., Matysiak K. 2013. Wild oat (Avena fatua L.) biotypes resistant to acetolactate synthase and acetyl-CoA carboxylase inhibitors in Poland. Plant Soil and Environment 59 (9): 432-437.

Adamczewski K., Matysiak K. 2009. Some biological aspects of Apera spica-venti (L.) P.B. Pamiętnik Puławski 150: 5-17.

Adamczewski K., Matysiak K. 2012. The mechanism of resistance to ALS-inhibiting herbicides in biotypes of wind bent grass (Apera spica-venti L.) with cross and multiple resistance. Polish Journal of Agronomy 10: 3-8.

Adamczewski K., Wagner J., Kierzek R. 2010. The quantification of the target-site resistance to mezosulfuron/jodosulfuron in a black-grass (Alopecurus myosuroides Huds.) biotype with a Pro197-to-His mutation from a winter wheat field in Poland using pot test and Petri dish assy. p. 24. In: Proceedings of the 15th European Weed Research Society Symposium. Kaposvar, Hungary, 12-15 January 2010, 337 pp.

Busi R., Yu Q., Barrett-Lennard R., Powles S. 2009. Pollen-mediated gene flow in Lolium rigidum over long distance. p. 339-343. In: Proceedings of XII-eme Colloque International sur la Biologie des Mauvaises Herbes. Dijon, France, 8-10 September 2009.

Cavan G., Cussans J., Moss S.R. 2000. Modelling different cultivation and herbicide strategies for their effect on herbicide resistance in Alopecurus myosuroides. Weed Research 40 (6): 561-568.

Chauvel B., Guillemin J.P., Colbach N., Gasques J. 2001. Evaluation of cropping systems for management of herbicideresistant populations of blackgrass (Alopecurus myosuroides Huds.). Crop Protection 20 (2): 127-137.

Cocker K.M., Moss S.R., Colemon J.O.D. 1999. Multiple mechanisms of resistance to fenoxaprop-P-ethyl in United Kingdom and other European populations of herbicideresistant Alopecurus myosuroides (black-grass). Pesticide Biochemistry and Physiology 65 (3): 169-180.

Délye C., Matéjicek A., Michel S. 2008. Cross-resistance patterns to ACCase-inhibiting herbicides conferred by mutant ACCase isoforms in Alopecurus myosuroides Huds. (blackgrass), re-examined at the recommended herbicide field rate. Pest Management Science 64 (11): 1179-1186.

Délye C., Menchari Y., Guillemin J.P., Matejicek A., Michel S., Camilleri C., Chauvel B. 2007. Status of black-grass (Alopecurus myosuroides) resistance to acetyl-coenzyme A carboxylase inhibitors in France. Weed Research 47 (2): 95-105.

Délye C., Straub C., Matejicek A., Michel S. 2003. Multiple origins of black-grass (Alopecurus myosuroides) target-site-based resistance to herbicides inhibiting acetyl-CoA carboxylase. Pest Management Science 60 (1): 35-41.

Hull R., Moss S. 2007. A rapid test for ALS herbicide resistance in black-grass (Alopecurus myosuroides). p. 151. In: Proceedings of the 14th European Weed Science Society (EWRS) Symposium, Hamar, Norway, 17-21 June 2007, 238 pp. 
Jalaludin A., Yu Q., Powles S.B. 2014. Multiple resistance across glufosinate, glyphosate, paraquat and ACCase-inhibiting herbicides in Eleusine indica population. Weed Research 55 (1): 82-89.

Jander G., Baerson S.R., Hudak J.A., Gonzalez K.A., Gruys K.J., Last R.L. 2003. Ethylmethanesulfonate saturation mutagenesis in Arabidopsis to determine frequency of herbicide resistance. Plant Physiology 131 (1): 139-146.

Kaundun S.S., Hutchings S.J., Dale R.P., McIndoe E. 2013. Role of a novel I1781T mutation and other mechanisms in conferring resistance to acetyl-CoA carboxylase inhibiting herbicides in a black-grass population. PLoS One 8 (7): e69568. DOI: 10.1371/journal.pone.0069568

Krysiak M., Gawroński S., Kierzek R., Adamczewski K. 2011. Molecular basis of blackgrass (Alopecurus myosuroides Huds.) resistance to sulfonylurea herbicides. Journal of Plant Protection Research 51 (2): 130-133.

Krzakowa M., Adamczewski K. 2011. Struktura genetyczna populacji wyczyńca polnego (Alopecurus myosuroides Huds.) określona zmiennością fosfoglukoizomerazy (PGI) i diaforazy (DIA) [Genetic structure of blackgrass (Alopecurus myosuroides Huds.) populations as revealed by phosphoglucose isomerase (PGI) and diaphorase (DIA) variability]. Progress in Plant Protection/Postępy w Ochronie Roślin 51 (1): 50-57.

Létouze A., Gasquez J. 2001. Inheritance of fenoxaprop-P-ethyl resistance in a blackgrass (Alopecurus myosuroides Huds.) population. Theoretical and Applied Genetics 103 (2): 288-296.

Léyouze A., Gasquez J. 2003. Enhanced activity of several herbicide-degrading enzymes: a suggested mechanism responsible for multiple resistance in blackgrass (Alopecurus myosuroides Huds.). Agronomie 23 (7): 601-608.

Milner L.J., Reade J.P., Cobb A.H. 2001. Developmental changes in glutatione S-transferase activity in herbicide-resistance populations of Alopecurus myosuroides Huds. (black-grass) in the field. Pest Management Science 57 (12): 1100-1106.

Moss S.R., Cocker K.M., Brown A.C., Hall L., Field L.M. 2003. Characterization of target-site resistance to ACCase-inhib- iting herbicides in the weed Alopecurus myosuroides (blackgrass). Pest Management Science 59 (2): 190-201.

Moss S.R., Cussans G.W. 1985. Variability in the susceptibility of Alopecurus myosuroides (black-grass) to chlorotoluron and isoproturon. Aspects of Applied Biology 99: 91-98.

Moss S.R., Peryman S.A.M., Tatnell L.V. 2007. Managing herbicide-resistant blackgrass (Alopecurus myosuroides): theory and practice. Weed Technology 21 (2): 300-309.

Moss S.R., Riches C., Stormonth D. 2012. Clethodim: its potential to combat herbicide-resistant Alopecurus myosuroides (black-grass). Aspects of Applied Biology 117: 39-45.

Petersen J., Dresbach-Runkel M., Wagner J. 2010. A method to determine the pollen-mediated spread of target-site resistance to acetylcoenzyme A carboxylase inhibitors in black grass (Alopecurus myosuroides Huds.). Journal of Plant Diseases and Protection 117 (3): 122-128.

Petersen J., Rosenhauer M. 2014. Current status of herbicide resistance in Alopecurus myosuroides in Europe. In: "Herbicide Resistance in Europe: Challenges, Opportunities and Threats." EWRS Working Group Meeting, Herbicide Resistance, Frankfurt am Main, Germany, 19 May 2014. Available on: www.ewrs.org/herbicide_resistance/programme. asp [Accessed on: 15 May 2016]

Price L.J., Moss S.R., Cole D.J., Harwood J.L. 2004. Graminicide resistance in a blackgrass (Alopecurus myosuroides) populations correlates with intensity of acetyl-CoA carboxylase. Plant Cell and Environment 27 (1): 15-26.

Rosenhauer M., Jaser B., Felsenstein F., Petersen J. 2013. Development of target-site resistance (TSR) in Alopecurus myosuroides in Germany between 2004-2012. Journal of Plant Diseases and Protection 120 (4): 179-187.

Saini R.K., Preston C., Malone J., Gill G. 2014. Molecular basis of resistance to clethodim in Australian ryegrass (Lolium rigidum) populations. p. 11-14. In: Proceedings of the 19th Australasian Weeds Conference, Hobart, Tasmania, Australia, 1-4 September 2014.

Yu Q., Han H., Vila-Aiub M.M., Powles S.M. 2010. AHAS herbicide resistance endowing mutations: effect on AHAS functionality and plant growth. Journal of Experimental Botany 61 (14): 3925-3934. 